\title{
Epidemiology of animal bites in Rafsanjan, southeast of Islamic Republic of Iran, 2003-05
}

\section{N.Z. Sheikholeslami, ${ }^{1}$ M. Rezaeian ${ }^{1}$ and Z. Salem ${ }^{2}$}

$$
\text { وبازئيات عضات شيخ الحيوانات في رفسنجان، جنوب بإنبان شرق جمهورية إيران الإسلامية. } 2003 \text { - } 2005
$$

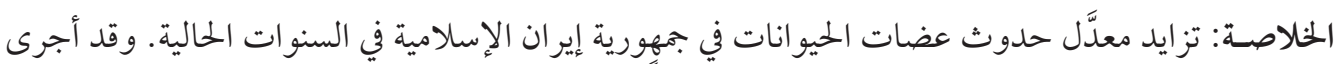

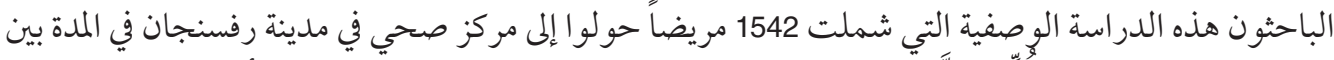

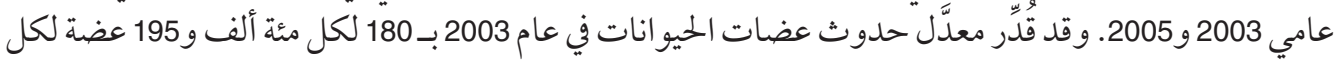

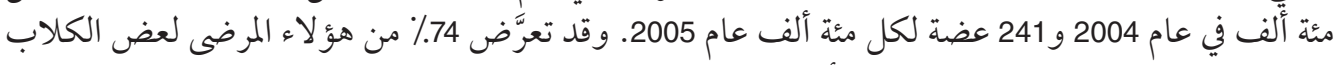

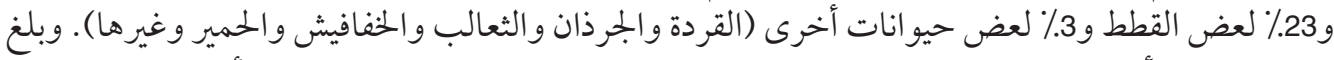

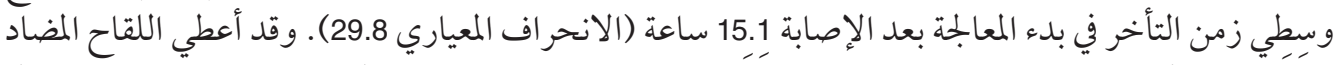

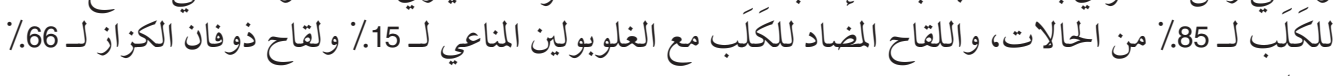

ABSTRACT The incidence of animal bites in the Islamic Republic of Iran has been increasing in recent years. In a descriptive study of 1542 patients referred to a health centre in Rafsanjan city from 2003 to 2005, the incidence of animal bites in the area was estimated as 180, 195 and 241 per 100000 in 2003, 2004 and 2005 respectively. Of the patients, $74 \%$ were bitten by dogs, $23 \%$ by cats and $3 \%$ by other animals (monkeys, rats, foxes, bats, donkeys, etc.). The mean time delay from injury to initial management was 15.1 (SD 29.8) hours. Rabies vaccine was given to $85 \%$ of cases, rabies vaccine plus rabies immunoglobulin to $15 \%$ and tetanus toxoid vaccine to $66 \%$.

\begin{abstract}
Épidémiologie des morsures d'animaux à Rafsanjan (sud-est de la République islamique d'Iran) en 2003-2005

RÉSUMÉ L'incidence des morsures d'animaux en République islamique d'Iran est en augmentation depuis quelques années. Dans une étude descriptive portant sur 1542 sujets dirigés vers un centre de santé de Rafsanjan entre 2003 et 2005, on a estimé l'incidence des morsures d'animaux dans la région respectivement à 180, 195 et 241 pour 100000 en 2003, 2004 et 2005. Sur l'ensemble des sujets, $74 \%$ avaient été mordus par des chiens, $23 \%$ par des chats et $3 \%$ par d'autres animaux (singes, rats, renards, chauves-souris, ânes, etc.). La durée moyenne entre la blessure et la prise en charge initiale était de 15,1 (E.T. 29,8) heures. Le vaccin antirabique a été administré à $85 \%$ des sujets, associé pour $15 \%$ d'entre eux à de l'immunoglobuline antirabique et pour $66 \%$ à de l'anatoxine tétanique.
\end{abstract}

${ }^{1}$ Department of Infectious Diseases; ${ }^{2}$ Department of Social Medicine, Rafsanjan Medical School, Rafsanjan,

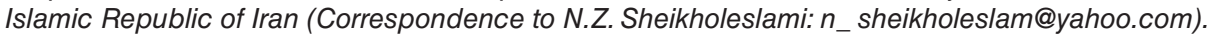

Received: 19/08/06; accepted: 05/11/06

المجلة الصحية لشرق المتوسط، منظمة الصحة العالمية، المجلد الخامس عشر، العدد Y، 9.ب 


\section{Introduction}

The incidence of animal bites in the Islamic Republic of Iran has been increasing in recent years [1]. Rafsanjan is a city in Kerman province in the south-east of the country which has many surrounding rural areas and has a population of around 250000 . This study reports the epidemiological profile of animal bites in Rafsanjan.

\section{Methods}

This descriptive study included a total of 1542 patients over a 3-year period 2003-05. Anyone who was bitten in any part of the area and referred to Rafsanjan health centre was the subject of the study. A questionnaire was completed by expert health care workers for each case.

Data were analysed using SPSS software, version 14, applying chi-squared and Student $t$-tests.

\section{Results}

There were 451 patients bitten in 2003 (84\% males and 16\% females), 488 in 2004 ( $86 \%$ males and 14\% females), and 603 in 2005 ( $87 \%$ males and $13 \%$ females). The incidence of animal bites in Rafsanjan was estimated as 180 per 100000,195 per 100000 and 241 per 100000 in 2003, 2004 and 2005 respectively.

Of all the patients, $1310(85 \%)$ were men and 277 (18\%) were children. The mean age and standard deviation (SD) was 27.0 (SD 17.1) years. The mean age in men was 26.6 (SD 16.3) years and in women 31.2 (SD 20.6) years $(P>0.05)$.

Of all patients, $74 \%$ were bitten by dogs, $23 \%$ by cats and $3 \%$ by other animals (monkeys, rats, foxes, bats, donkeys, etc.). The animals were domestic in $77 \%$ of cases, wild in $3 \%$ and stray animals in $20 \%$.
Examining the relation between area of residence and accident area, $45 \%$ of cases were bitten in urban areas while 55\% were bitten in rural areas. Furthermore, $6 \%$ of people who lived in urban areas were bitten in rural areas while $3 \%$ of rural residents was bitten in urban areas $(P=0.001)$.

Regarding the site of injury, $48 \%$ were to the hand, $34 \%$ the foot, $5 \%$ the head, $4 \%$ the trunk and the rest were mixed sites of injury. Overall, 15\% of cases had deep injuries, $70 \%$ had superficial injuries, 9\% had deep plus superficial injuries and the extent of injury was unknown for the rest of the cases. The proportion of deep injuries in men was higher than in women $(91 \%$ of males and $9 \%$ of females $)(P=0.018)$

The mean time delay from injury to initial management for both sexes was 15.1 (SD 29.8) hours. The mean delay for women was 11.6 (SD 29.6) hours and for men was 10.4 (SD 29.8) hours $(P>0.05)$.

Finally, $85 \%$ of cases received rabies vaccine, $15 \%$ received rabies vaccine plus rabies immunoglobulin and $66 \%$ received tetanus toxoid vaccine.

\section{Discussion}

The incidence of animal bites in different parts of the Islamic Republic of Iran has increased from 35.1 per 100000 in 1987 to 151 per 100000 in 2001 [1]. For instance, a report from Zanjan in north-west Islamic Republic of Iran showed that the incidence of animal bites increased from 56 per 100000 in 1994 to 194 per 100000 in 2004 [2]. Another report from Khorasan in the north of Islamic Republic of Iran also showed that the incidence of animal bites increased from 108 per 100000 in 2002 to 126 per 100000 in 2004 [3]. The same situation has been reported from Gazvin, Tehran and Kerman provinces [4]. In our study the incidence of animal bites in the Rafsanjan 
area was estimated as 180 per 100000,195 per 100000 and 241 per 100000 in 2003, 2004 and 2005 respectively.

In developing countries where canine rabies is common, most human cases result from dog bites, whereas in countries that domestic animals are vaccinated, most human cases follow exposure to rabid wild animals [5]. A recent study within the United States revealed that the number of human and canine rabies cases in the region fell by approximately $80 \%$ because of the mass vaccination of dogs and prophylactic treatments and as a result human rabies has been transmitted by wildlife, mostly by bats [6].
However, in our study $77 \%$ of cases were bitten by domestic animals mostly by dogs (74\%). The same situation has also been reported in Uganda [7] and Romania [8].

It seems that prevention strategies should focus on vaccination of all domestic animals, public education to avoid confronting wild and stray animals and advice to refer an injured person to health centres as soon as possible. Population control of stray animals, especially dogs, is an important strategy which needs cooperation among different sectors including the health, municipal and police forces.

\section{References}

1. Akbari M. The epidemiologic study of animal bites in Iran. Tehran, Islamic Republic of Iran, Ministry of Health and Ministry of Medical Education, 2001:34-5.

2. Sadeghi M, Mohamadi H, Taghiloo B. The epidemiologic study of animal bites in Zanjan (1994-2004). Paper presented at the 14th Iranian Congress of Infectious Diseases and Tropical Medicine, 17-21 December 2005, Tehran, Islamic Republic of Iran.

3. Jafary J, Yoosefnejad A. The epidemiologic study of animal bites in Khorasan (2002-2004). Paper presented at the 14th Iranian Congress of Infectious Diseases and Tropical Medicine, 17-21 December 2005, Tehran, Islamic Republic of Iran.

4. Akbari M. The epidemiologic study of animal bites in Iran. Tehran, Islamic Republic of Iran, Ministry of Health and Ministry of Medical Education, 2003-2005:50.

5. Turner GS. A review of the world epidemiology of rabies. Transactions of the Royal Society of Tropical Medicine and Hygiene, 1976, 70:175-8.

6. Belotto $A$ et al. Overview of rabies in the Americas. Virus research, 2005, 111(1):5-12.

7. Fèvre EM et al. The epidemiology of animal bite injuries in Uganda and projections of the burden of rabies. Tropical medicine and international health, 2005, 10(8):790-8.

8. Bocsan IS et al. Rabies surveillance in the rural population of Cluj County, Romania. Rural and remote health, 2005, 5(3):431. 